\title{
Sickle Cell Trait Appears to Increase the Risk of Hemorrhagic Stroke in African Adults with Dyslipidaemia: A Pilot Study
}

\author{
Olowoyo $\mathrm{P}^{1 *}$, Akinyemi RO ${ }^{2}$, Owolabi $\mathrm{MO}^{3}$, Fawale \\ $B^{4}$ and Ogunniyi $A^{5}$ \\ ${ }^{1}$ Neurology Unit, Department of Medicine, Federal \\ Teaching Hospital, Nigeria \\ ${ }^{2}$ Neuroscience and Ageing Research Unit, Institute for \\ Advanced Medical Research and Training, University of \\ Ibadan, Nigeria \\ ${ }^{3}$ Department of Medicine, University of Ibadan and \\ University, Nigeria \\ ${ }^{4}$ Neurology Unit, Department of Medicine, Obafemi \\ Awolowo University, Nigeria \\ ${ }^{5}$ Department of Medicine, University of Ibadan and \\ University, Nigeria \\ *Corresponding author: Olowoyo Paul, Department \\ of Medicine, Federal Teaching Hospital, Ido - Ekiti, \\ Nigeria
}

Received: May 28, 2017; Accepted: J une 19, 2017; Published: J uly 04, 2017

\begin{abstract}
Background: The association of sickle cell trait (HbAS) with stroke occurrence, type, and outcome is controversial. HbAS has now been regarded as a disease state such that a 10- fold increase in the risk of haemorrhagic stroke has been observed.

Objective: To confirm and quantify the effect of sickle cell trait on stroke type among Africans with and without cardiovascular risk factors.

Methods: This was pilot, analytical study conducted between 1st February, 2014 and 31st January, 2015 at the University College Hospital, Ibadan, Nigeria. All stroke patients, both ischaemic and haemorrhagic admitted during the study period had haemoglobin electrophoresis done and separated into two groups: $\mathrm{HbAS}$ as cases and $\mathrm{HbAA}$ as controls. Stroke was confirmed with brain CT scan or MRI. These groups were age- and- sex-matched; 35 cases and 35 controls. The severity of stroke within 24 hours of presentation was compared using the NIHSS and GCS within 24 hours of presentation. Also, cardiovascular risk factors were compared.
\end{abstract}

Results: We observed that the prevalence of haemorrhagic stroke was higher among the sickle cell trait patients (71.4\%) compared with age-and sexmatched controls with normal adult haemoglobin (45.7\%) $\mathrm{p}=0.02$, OR=2.9, $95 \% \mathrm{Cl}=1.10-7.99$. There was no significant difference in stroke severity at presentation between the two groups $p=0.10$. The only observable difference in the cardiovascular risk factors between the two groups was a significant higher prevalence of low HDLc among the sickle cell trait individuals (87.5\%), $p<0.001$.

Conclusion: We therefore concluded that the presence of sickle cell trait could be a risk factor for haemorrhagic stroke in Africans and may be related to the presence of low HDL-c.

Keywords: Sickle cell trait; Dyslipidaemia; Haemorrhagic stroke; Africa

\section{Introduction}

Intracerebral haemorrhage is defined as a focal collection of blood within the brain paraenchyma or ventricular system which is not due to trauma. It includes paraenchymal haemorrhage after CNS infarction [1]. In this type of stroke, the primary pathology is an area of bleeding causing direct damage to the brain tissue. I hospital based studies, It constitutes up to $37.0 \%-40.9 \%$ of all strokes in Nigeria $[2,3]$ with a significantly higher morbidity and mortality compared with ischaemic stroke. A 10 -fold increase in the risk of haemorrhagic stroke has been observed in individuals with HbAS [4]. It has also been found that there is a higher prevalence of haemoglobinopathies in patients with stroke than in the general population and that the existence of sickle cell trait in the population studied may reduce the age at onset of cerebral haemorrhage [5]. In the INTERSTROKE STUDY, [6] haemorrhagic stroke accounted for $34 \%$ of all stroke cases in the African cohort. Stroke mortality is quite high ranging from $35-45 \%$ [7-9]. Hence, the consideration of a factor, sickle cell trait, which is peculiar to the black race, that might be a contributor to why stroke is more severe with worse outcome among blacks compared with Caucasians [9].

Sickle cell trait (heterozygotes) describes a condition in which an individual has one abnormal allele of the $\beta$ haemoglobin gene (haemoglobin S) and a normal allele of the $\beta$ gene (haemoglobin A). The two alleles are co-dominant. The abnormal gene occurs as a result of glutamic acid-to-valine substitution at the sixth base position in the $\beta$ globin gene on chromosome 11 [10].

In Africa, the highest prevalence of HbAS occurs between latitudes $15^{\circ}$ North and $20^{\circ} \mathrm{S}$; ranging between $10 \%$ and $40 \%$ in some areas and specifically from $24-25 \%$ [11-13] in Nigeria. There is insufficient evidence to suggest an independent association between $\mathrm{HbAS}$ and stroke. The data relating to the association between HbAS and stroke are sparse in the literature and the available ones are case reports. Feldenzer, et al. [14] reported three cases of patients with sickle cell trait who developed superior sagittal sinus thrombosis with haemorrhagic infarct. These patients had normal vital signs and no risk factors for cardiovascular disease were identified. It was
Austin J Cerebrovasc Dis \& Stroke - Volume 4 Issue 4 - 2017 ISSN : 2381-9103 | www.austinpublishinggroup.com Olowoyo et al. (C) All rights are reserved
Citation: Olowoyo P, Akinyemi RO, Owolabi MO, Fawale B and Ogunniyi A. Sickle Cell Trait Appears to Increase the Risk of Hemorrhagic Stroke in African Adults with Dyslipidaemia: A Pilot Study. Austin J Cerebrovasc Dis \& Stroke. 2017; 4(4): 1067. 
Table 1: Socio-demographic characteristics of respondents.

\begin{tabular}{|c|c|c|c|}
\hline Demographic Characteristics & $\begin{array}{l}\text { Cases } \\
\mathrm{N}=35\end{array}$ & $\begin{array}{c}\text { Controls } \\
\mathrm{N}=35\end{array}$ & $p$-value \\
\hline Age (years) mean (SD) & $61.0(15.0)$ & $62.1(15.6)$ & 0.433 \\
\hline \multicolumn{4}{|l|}{ Sex n (\%) } \\
\hline Male & $20(57.1 \%)$ & $19(54.3 \%)$ & 0.810 \\
\hline Female & $15(42.9 \%)$ & $16(45.7 \%)$ & \\
\hline \multicolumn{4}{|l|}{ Ethnicity n (\%) } \\
\hline Yoruba & $32(91.4 \%)$ & $32(91.4 \%)$ & 0.148 \\
\hline Hausa & $0(0.0 \%)$ & $2(5.7 \%)$ & \\
\hline Igbo & $3(8.6 \%)$ & $1(2.9 \%)$ & \\
\hline \multicolumn{4}{|l|}{ Educational Status n (\%) } \\
\hline No formal education & $2(5.7 \%)$ & $6(17.1 \%)$ & 0.349 \\
\hline Primary & $6(17.1 \%)$ & $3(8.6 \%)$ & \\
\hline Secondary & $16(45.7 \%)$ & $14(40.0 \%)$ & \\
\hline Tertiary & $11(31.4 \%)$ & $12(34.3 \%)$ & \\
\hline \multicolumn{4}{|l|}{ Occupation n (\%) } \\
\hline Trading & $11(32.4 \%)$ & $22(62.9 \%)$ & 0.000 \\
\hline Artisan & $4(10.3 \%)$ & $4(10.3 \%)$ & \\
\hline Farmer & $10(29.4 \%)$ & $0(0.0 \%)$ & \\
\hline Civil Servant & $7(20.6 \%)$ & $6(17.1 \%)$ & \\
\hline Banker & $2(5.7 \%)$ & $1(2.9 \%)$ & \\
\hline
\end{tabular}

Table 2: Stroke severity at presentation between cases and controls.

\begin{tabular}{|c|c|c|c|}
\hline \multirow{2}{*}{ Category } & \multicolumn{2}{|c|}{ NIHSS } & \multirow{2}{*}{ p-value } \\
\cline { 2 - 3 } & $\leq \mathbf{2 0}$ & $\mathbf{2 0}$ & \\
\hline Cases & $20(57.1 \%)$ & $15(42.9 \%)$ & \multirow{2}{*}{0.21} \\
\hline Controls & $25(71.4 \%)$ & $10(28.6 \%)$ & \\
\hline
\end{tabular}

suggested that haemoglobin electrophoresis should be carried out in young black patients with unexplained neurologic symptoms or sign.

Also reported by Pai, et al. [15] was the case of an Arab teenage boy who presented with a sudden loss of vision in his left eye of one hour duration in which the ocular examination revealed acute central retinal artery occlusion. Blood investigations revealed sickle cell trait and abnormal partial thromboplastin time. No other contributing factors for this were identified.

Twelve cases have been reported in the literature that suggest the association of stroke with sickle cell trait; [16] the age range of the individuals affected being between 12 and 38 years. Wolman, et al. [17] reported a case of a 60 -year-old woman who was found to have the sickle cell trait with paraplegia. The patient died from respiratory failure and autopsy showed microinfarcts at various levels in the spinal cord resembling features of spinal cord embolism.

In another study, [18] it was observed that cases of stroke in sickle cell trait occurred by chance. Therefore, stroke was not considered to be associated with sickle cell trait. Also, there has not been any significant difference in the outcomes of stroke for sickle cell patients compared with normal haemoglobin [19]. In order to shed more light on this debatable association, a 24-year prospective epidemiological study was recently conducted observing an increased risk of ischaemic stroke in blacks with sickle cell trait [20]. In this study, the frequency of ischaemic stroke was slightly higher with sickle cell trait (13\%) than in participants with normal adult haemoglobin (10\%). The difference was not statistically significant. In multivariable analysis that controlled for the traditional risk factors for stroke, sickle cell trait was associated with a $40 \%$ higher risk of stroke [20]. Despite this, further investigation of the incidence and pathophysiology of stroke in patients with sickle cell trait is warranted. Since patients with sickle cell traits are usually asymptomatic and cannot be recognised by any facies or body shape unlike in patients with sickle cell anaemia $(\mathrm{Hb}$ SS), diagnosis by haemoglobin electrophoresis is required [21]. We set up this study to confirm and quantify the relationship between $\mathrm{HbAS}$ and stroke in the presence of other cardiovascular risk factors.

\section{Materials and Methods}

\section{Subjects, setting and procedure for data collection}

This was a pilot analytical study on first ever acute stroke patients attending the Emergency Department of the University College Hospital, Ibadan between 1st February, 2014 and January $31^{\text {th }} 2015$. These were stroke patients (both haemorrhagic and ischaemic) with sickle cell trait having first episode of stroke seen at the Emergency Department of the study location above. The age - and - sex matched stroke patients with Haemoglobin AA were recruited at the same time from the same hospital. All were Nigerians. All the subjects had their haemoglobin electrophoresis done before recruitment. Stroke was confirmed in all subjects by brain CT scan or MRI.

\section{Selection criteria}

Consecutive consenting Nigerian stroke patients with sickle cell trait having first ever stroke confirmed with brain CT scan or MRI that presented within seven days of stroke onset were included. Stroke patients who were unable to communicate because of severe stroke, aphasia or dementia but with valid surrogate respondents (spouse or first degree relatives who had lived with the patients in the last one year) were also included. Patients with repeat stroke, sickle cell anaemia or sickle cell disease e.g. Hb SS, Hb SC, Hb AC, lack of consent, and no neuroimaging done were excluded.

\section{Control group}

These were age- and- sex matched Nigerians who developed first episode of stroke and presented within seven days of onset during the period of study and who had haemoglobin AA. They had their stroke confirmed with neuroimaging and gave consent to be recruited.

\section{Statistical analysis}

Data analysis was done using the Statistical Package for the Social Sciences (SPSS), version 16(SPSS Inc., Chicago, IL, U.S.A.) and all generated data were presented as mean \pm S.D, median, frequencies and percentages. For variables with normal distribution, comparison between groups was performed using independent t-test. Correlation between continuous variables was tested using Spearman's correlation coefficient. Relationship between categorical variables was done using Chi-square test. A 5\% significance level $(P$-value $<0.05)$ was considered significant. Univariate and Multivariate logistic regression analyses adjusting for potential confounders (cardiovascular risk factors for stroke) were also performed. 


\section{Ethical approval}

Ethical clearance was obtained from the University of Ibadan/ University College Hospital Health Research Joint Institutional Review Board.

\section{Procedure}

Informed consent was obtained from the subjects and controls. The following information was obtained: age, gender, occupation, level of education, history of hypertension, diabetes mellitus, and stroke.

All subjects had their blood samples collected from the right or left cubital vein after the overlying skin had been cleaned with $70 \%$ methylated spirit. Five millilitres (mls) of blood was collected in lithium heparin bottles for plasma lipid profile analysis after an 8-12-hour fast. The lipid profile was determined using the Randox Laboratories Limited UK kits, Total Cholesterol (TC) was determined by the enzymatic endpoint method, [22] triglycerides (TG) by the enzymatic- colorimetric method, and high density lipoprotein cholesterol (HDL) determined by the precipitation method [23]. Low density lipoprotein (LDL) was calculated using the Friedwald's formula, [24] LDL=TC-HDL- (TG/2.2) in mmol/l or LDL=TC-HDL- (TG/5) in $\mathrm{mg} / \mathrm{dl}$, when plasma TG concentration $<4.52 \mathrm{mmol} / \mathrm{l}(400 \mathrm{mg} / \mathrm{dl})$. Five millilitres of blood was collected in sodium fluorite bottle using the plasma to determine the fasting blood glucose level by the glucose oxidase method, [25] using the Randox Laboratories Limited United Kingdom (UK) Glucose (GLU PAP) kit. Haemoglobin phenotype and haemoglobin S quantification were determined using 2 millilitres of venous blood collected in EDTA bottles with high performance liquid chromatography (HPLC) at the Genetic Laboratory of the Institute for Advanced Medical Research and Training of the College of Medicine, University of Ibadan.

In the laboratory, all blood samples from the stroke patients were initially screened by the use of the Haemoglobin Electrophoretic Tank to determine those who were having sickle cell trait and normal adult haemoglobin. Those with sickle cell anaemia (HbSS), sickle cell disease and other traits such as haemoglobins AC, SC were excluded. Hemoglobin S quantification was then carried out on the samples of the cases (HbAS subjects) using a high performance liquid chromatography method (VARIANT II Haemoglobin Testing System).

The level of stroke severity was assessed within 24 hours of admission using the National Institute of Health Stroke Scale. The Glasgow Coma Scale Score was also assessed at presentation. Diagnosis of stroke was confirmed with brain CT or brain MRI while stroke mimics were ruled out (Table 1).

\section{Results}

\section{Comparison of stroke severity at presentation between HbAS and HbAA groups}

Twenty (57\%) of the cases had moderate stroke while 15 (42\%) had severe stroke. Among the controls, 25 (71.4\%) had moderate stroke and $10(28.6 \%)$ had severe stroke. The difference of the two groups failed to reach statistical significance $(\mathrm{p}=0.21)$. This is depicted in Table 2 below.
Table 3: Comparison of Glasgow Coma Score between cases and controls at presentation.

\begin{tabular}{|c|c|c|c|}
\hline \multirow{2}{*}{ Category } & \multicolumn{2}{|c|}{ GCS } & \multirow{2}{*}{ p-value } \\
\cline { 2 - 3 } & $\leq 8$ & $>8$ & \\
\hline Cases & $13(41.9 \%)$ & $18(58.1 \%)$ & \multirow{2}{*}{0.21} \\
\hline Controls & $25(71.4 \%)$ & $10(28.6 \%)$ & \\
\hline
\end{tabular}

Table 4: Cardiovascular risk factors among cases and controls.

\begin{tabular}{|c|c|c|c|}
\hline Risk factor & Cases & Controls & p-value \\
\hline Age $<70$ years & $26(74.3 \%)$ & $23(65.7 \%)$ & \multirow{2}{*}{0.40} \\
\hline Age $\geq 70$ years & $9(25.7 \%)$ & $12(34.3 \%)$ & \\
\hline Blood glucose < 140 mg/dl & $23(74.2 \%)$ & $30(85.7 \%)$ & \multirow{2}{*}{0.30} \\
\hline Blood glucose $\geq 140 \mathrm{mg} / \mathrm{dl}$ & $8(25.8 \%)$ & $5(14.3 \%)$ & \\
\hline Systolic BP $\geq 140 \mathrm{mmHg}$ & $7(21.2 \%)$ & $5(14.3 \%)$ & \multirow{2}{*}{0.40} \\
\hline Systolic BP < 140 mmHg & $26(78.8 \%)$ & $30(85.7 \%)$ & \\
\hline Diastolic BP $<90$ mmHg & $12(36.4 \%)$ & $16(45.7 \%)$ & \multirow{2}{*}{0.40} \\
\hline Diastolic BP $\geq 90 \mathrm{mmHg}$ & $21(63.6 \%)$ & $19(53.3 \%)$ & \\
\hline $\mathrm{LDL}<100 \mathrm{mg} / \mathrm{dl}$ & $8(33.3 \%)$ & $5(14.3 \%)$ & \multirow{2}{*}{0.08} \\
\hline $\mathrm{LDL} \geq 100 \mathrm{mg} / \mathrm{dl}$ & $16(66.7 \%)$ & $30(85.7 \%)$ & \\
\hline $\mathrm{HDL}<50 \mathrm{mg} / \mathrm{dl}$ & $21(87.5 \%)$ & $7(20.0 \%)$ & \multirow{2}{*}{0.00} \\
\hline $\mathrm{HDL} \geq 50 \mathrm{mg} / \mathrm{dl}$ & $3(12.5 \%)$ & $28(80.0 \%)$ & \\
\hline Triglyceride < 150 mg/dl & $19(79.2 \%)$ & $34(97.1 \%)$ & \multirow{2}{*}{0.02} \\
\hline Triglyceride $\geq 150 \mathrm{mg} / \mathrm{dl}$ & $5(20.8 \%)$ & $1(2.9 \%)$ & \\
\hline Total Chol. $<200$ mg/dl & $13(54.2 \%)$ & $12(34.3 \%)$ & \multirow{2}{*}{0.10} \\
\hline Total Chol. $\geq 200 \mathrm{mg} / \mathrm{dl}$ & $11(45.8 \%)$ & $23(65.7 \%)$ & \\
\hline
\end{tabular}

The relationship between sickle cell trait and Glasgow coma score at presentation

Thirteen $(41 \%)$ cases and $25(71 \%)$ controls had GCS score of 8 and below at presentation while $18(58.1 \%)$ of the cases and 10 (28.6\%) of the controls had a GCS score $>8$ at presentation. This did not show any statistical significance. $(\mathrm{p}=0.21)$. This is shown in Table 3,4 below.

\section{Discussion}

\section{Demographic characteristics}

The mean age of 62.1 years in this study for both the cases and controls is similar to findings in other previous studies from the South western part of Nigeria [26]. There was a slight male preponderance in this study similar to many other hospital-based studies $[27,28]$. Some of the reasons attributed to the male preponderance were the enhanced risk for thrombotic stroke and higher presence of cardiovascular risk factors in them [29].

\section{Relationship between sickle cell trait and stroke severity at presentation}

There was no statistically significant difference in stroke severity at presentation between the sickle cell trait individuals and the age-and sex- matched haemoglobin AA patients in this study. In a prospective study by Stark, et al. [30], there was no evidence of excess mortality or differential causes of mortality between HbAS and HbAA individuals. Also, in a study on blood pressure and other cardiovascular disease risk factors in black civil servant adults in Benin 
City, Nigeria by Nwankwo, et al., there was no significant difference in the cardiovascular risk factors between normal subjects and sickle cell trait [31]. Our study was conducted among stroke individuals that were expected to constellations of cardiovascular risk factors which may explain why we were able to detect low HDLc among the cases. Therefore, stroke was expected to be worse at presentation among the cases in this study but the small sample size might be the reason for the lack of statistically significant difference. However, other factors such as the volume and location of intracerebral haemorrhage that are determinants of stroke severity and prognosis were not considered [32].

\section{Types of stroke in patients with sickle cell trait compared with the types in patients with normal adult haemoglobin}

Haemorrhagic stroke was more common among the sickle cell trait patients than among the patients with normal adult haemoglobin in this study. Some studies have found haemorrhagic stroke to be commoner in adults with sickle cell disease as a result of the development of moyamoya disease [33,34] which results from the formation of poorly endothelialised vessels following vascular occlusion. In most studies on the pattern of stroke in Nigeria, ischaemic stroke has always been the more common [35-38] except in a few cases in urban centres [39] in one of which Ogun, et al. used the WHO criteria to classify the stroke types. The significant difference between the two groups in this study in terms of the pathologic stroke types is likely to be due to the presence of sickle cell trait in line with the observation of Ajayi, et al. [4] in their study that the risk of haemorrhagic stroke was 10 times that of ischaemic stroke in sickle cell patients. Owolabi, et al. in the Berlin- Ibadan experience, observed that cerebral haemorrhage was less common (20\%) in Berlin than in Ibadan (37\%) [2]. An observable reason for the higher prevalence of haemorrhagic stroke among the cases is the significant higher proportion of low HDLc in them. A low HDL-c has also been found as a risk factor for haemorrhagic stroke in black Africans [40]. This could cause atherogenesis in the cerebral vessels and development of poorly endothelialized collateral circulation which is susceptible to rupture most especially when hypertension among other cardiovascular risk factors supervenes.

\section{Conclusion}

The presence of sickle cell trait appears to be associated with haemorrhagic stroke most especially when dyslipidaemia is present. Particular attention should be paid to the modifiable cardiovascular risk factors in sickle cell trait individuals to forestall haemorhagic stroke.

\section{Strength}

Neuroimaging was done in all the patients to confirm stroke diagnosis and categorically classify stroke into ischaemic and haemorrhagic. Sickle cell trait was confirmed with the use of the HPLC machine.

\section{Limitation}

This study was limited by the small sample size; though a Pilot study, larger studies such as the SIREN study are needed to confirm this observation. The volume of the haemorrhage was not calculated in this study to correlate with severity at presentation as there were varying time intervals between stroke onset and presentation. The locations of intracerebral haemorrhage also were not determined.

\section{Acknowledgement}

Stroke Investigative Research and Education Network (SIREN) projects.

\section{References}

1. Sacco RL, Kasner SE, Broderick JP, Caplan LR, Culebras A, Elkind MS, et al. An updated definition of stroke for the 21st century a statement for healthcare professionals from the American Heart Association/American Stroke Association. Stroke. 2013; 44: 2064-2089.

2. Owolabi MO, Ugoya S, Platz T. Racial disparity in stroke risk factors: the Berlin-Ibadan experience; a retrospective study. Acta Neurol Scand. 2009; 119: 81-87.

3. Owolabi L, Ibrahim A. Stroke in young adults: a prospective study from Northwestern Nigeria. ISRN Neurol. 2012; 2012: 468706.

4. Ajayi AA. Should the sickle cell trait be reclassified as a disease state? Eur J Intern Med. 2005; 16: 463.

5. Napon C, Kaboré A, Ouédraogo M, Dravé A, Lompo L, Kaboré J. Strokes and hemoglobinopathies in Burkina Faso. Med Sante Trop. 2012; 22: 390-393.

6. O'Donnell MJ, Xavier D, Liu L, Zhang H, Chin SL, Rao-Melacini P, et al. Risk factors for ischaemic and intracerebral haemorrhagic stroke in 22 countries (the INTERSTROKE study): a case-control study. Lancet. 2010; 376:112123.

7. Komolafe $M$, Ogunlade O, Komolafe EO. Stroke mortality in a teaching hospital in South Western Nigeria. Trop Doct. 2007; 37: 186-188.

8. Ekeh B, Ogunniyi A, Isamade E, Ekrikpo U. Stroke mortality and its predictors in a Nigerian teaching hospital. Afr Health Sci. 2015; 15: 74-81.

9. Jones MR, Horner RD, Edwards LJ, Hoff J, Armstrong SB, Smith-Hammond CA, et al. Racial variation in initial stroke severity. Stroke. 2000; 31: 563-567.

10. Stuart MJ, Nagel RL. Sickle-cell disease. Lancet. 2004; 364: 1343-1360.

11. Taiwo IA, Oloyede OA, Dosumu AO. Frequency of sickle cell genotype among the Yorubas in Lagos: Implications for the level of awareness and genetic counseling for sickle cell disease in Nigeria. J Community Genet. 2011; 2: 13-18.

12. Serjeant GR. Mortality from sickle cell disease in Africa: Interventions used to reduce mortality in non-malarial areas may be inappropriate. BMJ. 2005; 330: $432-433$.

13. Okwi AL, Byarugaba W, Ndugwa CM, Parkes A, Ocaido M, Tumwine JK. An up-date on the prevalence of sickle cell trait in Eastern and Western Uganda. BMC Blood Disord. 2010; 10: 5.

14. Feldenzer JA, Bueche MJ, Venes JL, Gebarski SS. Superior sagittal sinus thrombosis with infarction in sickle cell trait. Stroke. 1987; 18: 656-660.

15. Pai SA, Hebri SP, Dekhain MA. Spontaneous central retinal artery occlusion in a teenager with sickle cell trait. Middle East Afr J Ophthalmol. 2015; 22: 119-121.

16. Radhakrishnan K, Thacker A, Maloo J, El-Mangoush M. Sickle cell trait and stroke in the young adult. Postgrad Med J. 1990; 66: 1078-1080.

17. Wolman L, Hardy AG. Spinal cord infarction associated with the sickle cell trait. Paraplegia. 1970; 7: 282-291.

18. Sears DA. The morbidity of sickle cell trait: a review of the literature. Am J Med. 1978; 64: 1021-1036.

19. John N. A review of clinical profile in sickle cell traits. Oman Med J. 2010 25: 3-8.

20. Caughey MC, Loehr LR, Key NS, Derebail VK, Gottesman RF, Kshirsagar $\mathrm{AV}$, et al. Sickle cell trait and incident ischemic stroke in the Atherosclerosis Risk in Communities study. Stroke. 2014; 45: 2863-2867. 
21. Hindmarsh PC, Brozovic M, Brook CG, Davies SC. Incidence of overt and covert neurological damage in children with sickle cell disease. Postgrad Med J. $1987 ; 63: 751-753$

22. Roeschlau P, Bernt E, Gruber W. Enzymatic determination of total cholesterol in serum. Z Klin Chem Klin Biochem. 1974; 12: 226.

23. Lopes-Virella MF, Stone P, Ellis S, Colwell JA. Cholesterol determination in high-density lipoproteins separated by three different methods. Clin Chem. 1977; 23: 882-884

24. Friedewald WT, Levy RI, Fredrickson DS. Estimation of the concentration of low-density lipoprotein cholesterol in plasma, without use of the preparative ultracentrifuge. Clin Chem. 1972; 18: 499-502.

25. Barham D, Trinder P. An improved colour reagent for the determination of blood glucose by the oxidase system. Analyst. 1972; 97: 142-145.

26. Danesi M, Okubadejo N, Ojini F. Prevalence of stroke in an urban, mixedincome community in Lagos, Nigeria. Neuroepidemiology. 2006; 28: 216-223.

27. Obiako O, Oparah S, Ogunniyi A. Prognosis and outcome of acute stroke in the University College Hospital Ibadan, Nigeria. Niger J Clin Pract. 2011; 14: 359-362.

28. Owolabi L, Nagoda M. Stroke in developing countries: Experience at Kano, Northwestern Nigeria. Stroke. 2012; 7

29. Komolafe MA, Komolafe EO, Fatoye F, Adetiloye V, Asaleye C, Famurewa O, et al. Profile of Stroke in Nigerians: A Prospective Clinical Study Profi Des Accidents Vasculaires Cerebraux Au Nigeria: Une Etude Prospective. Sommaire/Table of Contents. 2007; 26: 5 .

30. Stark AD, Janerich DT, Jereb SK. The incidence and causes of death in a follow-up study of individuals with haemoglobin AS and AA. Int J Epidemiol. 1980; 9: 325-328.
31. Nwankwo MU, Bunker $\mathrm{CH}$, Ukoli FA, Omene JA, Freeman DT, Vergis EN et al. Blood pressure and other cardiovascular disease risk factors in black adults with sickle cell trait or glucose-6-phosphate dehydrogenase deficiency. Genet Epidemiol. 1990; 7: 211-218.

32. Davis S, Broderick J, Hennerici M, Brun N, Diringer M, Mayer S, et al. Hematoma growth is a determinant of mortality and poor outcome after intracerebral hemorrhage. Neurology. 2006; 66: 1175-1181.

33. Kuroda S, Ishikawa T, Houkin K, Nanba R, Hokari M, Iwasaki Y. Incidence and clinical features of disease progression in adult moyamoya disease. Stroke. 2005; 36: 2148-2153.

34. Kuroda S, Hashimoto N, Yoshimoto T, Iwasaki Y. Radiological findings, clinical course, and outcome in asymptomatic moyamoya disease. Stroke. 2007; 38: 1430-1435

35. Onwuchewa A, BellGam H, Asekomeh Gs. Stroke at the university of port Harcourt teaching hospital, rivers state, Nigeria. Tropical doctor. 2009; 39: 150-152.

36. Bwala SA. Stroke in a subsaharan Nigerian hospital--a retrospective study. Trop Doct. 1989; 19: 11-14.

37. Osuntokun BO. Stroke in the Africans. Afr J Med Med Sci. 1977; 6: 39-53.

38. Desalu OO, Wahab KW, Fawale B, Olarenwaju TO, Busari OA, Adekoya AO, et al. A review of stroke admissions at a tertiary hospital in rural Southwestern Nigeria. Ann Afr Med. 2011; 10: 80-85.

39. Ogun SA, Ojini FI, Ogungbo B, Kolapo KO, Danesi MA. Stroke in south west Nigeria: a 10-year review. Stroke. 2005; 36: 1120-1122.

40. Owolabi MO, Agunloye AM. Which risk factors are more associated with ischemic rather than hemorrhagic stroke in black Africans? Clin Neurol Neurosurg. 2013; 115: 2069-2074.
Austin J Cerebrovasc Dis \& Stroke - Volume 4 Issue 4 - 2017 ISSN : 2381-9103 | www.austinpublishing group.com

Olowoyo et al. ( ) All rights are reserved
Citation: Olowoyo P, Akinyemi RO, Owolabi MO, Fawale B and Ogunniyi A. Sickle Cell Trait Appears to Increase the Risk of Hemorrhagic Stroke in African Adults with Dyslipidaemia: A Pilot Study. Austin J Cerebrovasc Dis \& Stroke. 2017; 4(4): 1067. 